\title{
Fate and Transport of Uranium (VI) in Weathered Saprolite
}

11

${ }^{1}$ Civil Engineering Division, Samsung C\&T Corp., Seocho-Dong, Seocho-Gu, Seoul, Korea 137-956;

${ }^{2}$ Oak Ridge National Laboratory, Environmental Sciences Division, P.O. Box 2008, MS 6038, Oak Ridge, TN 37831-6038, USA;

${ }^{3}$ Key Laboratory of Tibetan Environment Changes and Land Surface Processes, Institute of Tibetan Plateau Research, Chinese Academy of Sciences, P.O. Box 2871, Beijing, 100085, China;

${ }^{4}$ Department of Civil and Environmental Engineering, University of Tennessee, Knoxville, Knoxville, TN 37996, USA.;

${ }^{5}$ Oak Ridge National Laboratory, Biosciences Division, P.O. Box 2008, MS 6036, Oak Ridge, TN 37831-6036, USA;

${ }^{6}$ Faculty of Earth System and Environmental Sciences, Chonnam National University, 300 Yongbong-Dong, Buk-Gu, Gwangju, 500-757, Korea.

* Corresponding Author, Phone: 865-574-6398; Fax: 865-576-8646; E-mail: brookssc@ornl.gov

Notice: This manuscript has been authored by UT-Battelle, LLC, under contract DE-AC05-000R22725 with the U.S. Department of Energy. The United States Government retains and the publisher, by accepting the article for publication, acknowledges that the United States Government retains a non-exclusive, paid-up, irrevocable, world-wide license to publish or reproduce the published form of this manuscript, or allow others to do so, for United States Government purposes. 


\section{ABSTRACT}

2 Batch and column experiments were conducted to investigate sorption and transport of uranium

3 (U) in the presence of saprolite derived from interbedded shale, limestone, and sandstone

4 sequences. Sorption kinetics were measured at two initial concentrations $\left(\mathrm{C}_{0} ; 1,10 \mu \mathrm{M}\right)$ and

5 three soil:solution ratios $\left(\mathrm{R}_{\mathrm{s} / \mathrm{w}} ; 0.005,0.25,2 \mathrm{~kg} / \mathrm{L}\right)$ at $\mathrm{pH} 4.5$ ( $\mathrm{pH}$ of the saprolite). The rate of $\mathrm{U}$

6 loss from solution ( $\mu$ mole/L/h) increased with increasing $R_{s / w}$. Uranium sorption exhibited a fast

7 phase with $80 \%$ sorption in the first eight hours for all $\mathrm{C}_{0}$ and $\mathrm{R}_{\mathrm{s} / \mathrm{w}}$ values and a slow phase

8 during which the reaction slowly approached (pseudo)equilibrium over the next seven days. The

9 pH-dependency of $\mathrm{U}$ sorption was apparent in $\mathrm{pH}$ sorption edges. $\mathrm{U}(\mathrm{VI})$ sorption increased over

10 the $\mathrm{pH}$ range 4 to 6 , then decreased sharply at $\mathrm{pH}>7.5$. U(VI) sorption edges were well

11 described by a surface complexation model using calibrated parameters and the reaction network

12 proposed by Waite et al. (1994). Sorption isotherms measured using the same $\mathrm{R}_{\mathrm{s} / \mathrm{w}}$ and $\mathrm{pH}$

13 values showed a solids concentration effect where U(VI) sorption capacity and affinity decreased

14 with increasing solids concentration. This effect may have been due to either particle

15 aggregation or competition between $\mathrm{U}(\mathrm{VI})$ and exchangeable cations for sorption sites. The

16 surface complexation model with calibrated parameters was able to predict the general sorption

17 behavior relatively well, but failed to reproduce solid concentration effects, implying the

18 importance of appropriate design if batch experiments are to be utilized for dynamic systems.

19 Transport of U(VI) through the packed column was significantly retarded. Transport simulations

20 were conducted using the reactive transport model HydroGeoChem (HGC) v5.0 that

21 incorporated the surface complexation reaction network used to model the batch data. Model

22 parameters reported by Waite et al. (1994) provided a better prediction of $\mathrm{U}$ transport than

23 optimized parameters derived from our sorption edges. The results presented in this study 
1 highlight the challenges in defining appropriate conditions for batch-type experiments used to

2 extrapolate parameters for transport models, and also underline a gap in our ability to transfer 3 batch results to transport simulations.

4 


\section{1. INTRODUCTION}

3 Uranium (U) is a major contaminant in soils at U.S. Department of Energy (DOE) weapons

4 processing plants (RILEY et al., 1992). At the DOE plant in Oak Ridge, Tennessee, uranium

5 isotopes were separated using an electromagnetic process and U-bearing wastes disposed on site.

6 Soils at the waste disposal site in Oak Ridge are composed largely of weathered saprolite, similar

7 to many other areas in the southeastern USA (LI et al., 1997; VEPRASKAS et al., 1991). Although

8 groundwater flow and contaminant transport are not easily predicted due to the complex flow

9 mechanism through saprolite (JARDINE et al., 1990; MAYES et al., 2003; Zhang et al., 2011),

10 understanding contaminant transport is important to effectively remediate these disposal sites.

12 Uranium is most soluble and mobile in the hexavalent oxidation state (U(VI); (DUFF et al., 2002).

13 Due to concern over the environmental and human health hazards associated with U(VI),

14 sorption of U(VI) onto a range of soil solids has been comprehensively investigated. The U(VI)

15 sorption studies using pure iron-containing minerals such as ferrihydrite (ALLARD et al., 1999;

16 Morrison et al., 1995; MOYES et al., 2000; WAITE et al., 1994), goethite (COMBES et al., 1992;

17 KOHLER et al., 1992; TRIPATHI, 1984), hematite (BARGAR et al., 1999; HSI and LANGMUIR, 1985;

18 TICKNOR, 1994; TRIPATHI, 1984), and phyllite (ARNOLD et al., 2001) showed that iron-

19 containing minerals strongly adsorb U(VI). Sorption of U(VI) to clay minerals such as

20 montmorillonite (MCKINLEY et al., 1995) and beidellite-dominated smectite (TURNER et al., 1996)

21 were also studied. Other pure materials investigated for U(VI) sorption include sulfides (WERSIN

22 et al., 1994), carbonates (MORSE et al., 1984), and various mixed materials (BARNETT et al., 2000;

23 WAITE et al., 2000). Using three different heterogeneous soils with nearly identical iron oxide 
1 contents, Barnett et al. (2000) concluded that the interaction of U(VI) with iron oxides controlled

2 U(VI) sorption onto the soils studied. The overall conclusion of these batch studies, using either

3 pure or heterogeneous materials, was that $\mathrm{U}(\mathrm{VI})$ is strongly adsorbed though the degree of

4 sorption is affected by chemical conditions.

6 Concerns have been raised about the extrapolation of batch results to dynamic systems. The

7 difficulty utilizing batch-derived parameters for transport model simulations likely results from

8 conditions in the column that are not adequately represented in the batch experiment (KOHLER et

9 al., 1996). Transport model simulations with surface complexation parameters independently

10 estimated from batch experiments was not able to accurately predict U(VI) transport through

11 columns packed with quartz grains (KOHLER et al., 1996). Uranium transport through sandstone

12 columns was poorly predicted by coupled chemical equilibrium transport models (Sims et al.,

13 1996). Barnett et al. (2000) also reported that simulations using batch experiment results did not

14 adequately predict U(VI) breakthrough curves (BTC's) from soil columns and suggested a rate-

15 limited reaction in the columns as a possible explanation. Gamerdinger et al. (GAMERDINGER et

16 al., 2001) reached a similar conclusion because the high velocity flow used in their transport

17 experiment resulted in less sorption than expected from the batch equilibrium test. Therefore,

18 the appropriate design of batch experiments is necessary to obtain results that are useful for

19 predicting $\mathrm{U}(\mathrm{VI})$ transport.

21 The objectives of this study are to investigate the rate and extent of U(VI) sorption onto saprolite

22 under various conditions and discuss the implications of these results with respect to predicting 
$1 \mathrm{U}(\mathrm{VI})$ transport. We employed three different soil:solution ratios and two initial U(VI)

2 concentrations to study the implications of various conditions on U(VI) sorption onto saprolite.

4 2. MATERIALS AND METHODS

\section{2.1. Preparation and characterization of saprolite}

8 The sampling site was located on the ERSP Field Research Center (FRC) Background Site at

9 Oak Ridge National Laboratory in East Tennessee (http://www.esd.ornl.gov/nabirfrc/) which is

10 free of $\mathrm{U}$ contamination but is underlain by the same geologic formations as $\mathrm{U}$ waste disposal

11 areas on site. Bulk samples of saprolite derived from interbedded shale, limestone, and

12 sandstone sequences were collected from the $\mathrm{C}$ horizon approximately $1 \mathrm{~m}$ below the surface.

13 Black manganese oxides were observed on fracture surfaces in the saprolite. Samples were

14 transported to the laboratory and maintained at room temperature in sealed plastic bags. The

15 samples were then crushed and sieved through a $2 \mathrm{~mm}$ screen prior to use in experiments.

16 Chemical, physical, and mineralogical properties of the saprolite used in this study were

17 determined and are provided in Table 1. 
1 All batch sorption experiments (edges, isotherms and kinetics) were conducted in $30 \mathrm{~mL}$

2 polycarbonate centrifuge tubes (Nalge Company) under ambient air at constant ionic strength

3 (0.05 M adjusted with $\left.\mathrm{NaNO}_{3}\right)$. Uranium solutions were prepared from depleted $\mathrm{UO}_{2}\left(\mathrm{NO}_{3}\right)_{2}$ salt.

4 Kinetic experiments were performed at two initial concentrations $\left(\mathrm{C}_{0} ; 1\right.$ and $\left.10 \mu \mathrm{M}\right)$ and three 5 soil:solution ratios $\left(\mathrm{R}_{\mathrm{s} / \mathrm{w}}\right)$ of $0.005,0.25$, and $2 \mathrm{~kg} / \mathrm{L}$ at $\mathrm{pH} 4.5$ (pH of the saprolite). For $\mathrm{R}_{\mathrm{s} / \mathrm{w}}$ of

$6 \quad 0.005$ and $0.25 \mathrm{~kg} / \mathrm{L}, 0.1 \mathrm{~g}$ and $5 \mathrm{~g}$ of soil, respectively, were equilibrated with $20 \mathrm{~mL}$ of the

7 U(VI)-bearing solution. For $\mathrm{R}_{\mathrm{s} / \mathrm{w}}$ of $2 \mathrm{~kg} / \mathrm{L}, 4 \mathrm{ml}$ of $\mathrm{U}(\mathrm{VI})$ solution were added to $8 \mathrm{~g}$ of soil. The

8 soil-solution samples were shaken from $1 \mathrm{~min}$ to 7 days on a reciprocating shaker table. The $\mathrm{R}_{\mathrm{s} / \mathrm{w}}$

9 values were chosen based on (i) reported values used in other $\mathrm{U}$ sorption studies $\left(\mathrm{R}_{\mathrm{s} / \mathrm{w}}=0.005\right.$;

10 (BARNETT et al., 2002; BARNETT et al., 2000; WAITE et al., 1994), (ii) the value recommended by

11 the ASTM standard sorption protocol $\left(\mathrm{R}_{\mathrm{s} / \mathrm{w}}=0.25\right.$; ASTM D4646-03; (PORRO et al., 2000), and

12 (iii) a value that approximates conditions in some laboratory transport experiments $\left(\mathrm{R}_{\mathrm{s} / \mathrm{w}}=2\right.$;

13 (BARNETT et al., 2000; Porro et al., 2000).

15 Sorption edges were measured using two soil:solution ratios of 0.005 and $0.25 \mathrm{~kg} / \mathrm{L}$. The

16 solution $\mathrm{pH}$ of $\mathrm{U}$ free samples was adjusted with $0.1 \mathrm{M} \mathrm{NaOH}$ or $\mathrm{HNO}_{3}$ and then bubbled with

17 moist air until a constant $\mathrm{pH}$ was reached. The samples were then spiked with $\mathrm{U}(\mathrm{VI})$ stock

18 solution to achieve the target initial $\mathrm{U}(\mathrm{VI})$ concentration of $4.2 \mu \mathrm{M}$ and equilibrated for 4 days

19 prior to sampling. Preliminary kinetic tests indicated that this was sufficient time to achieve

20 steady-state $\mathrm{U}$ concentrations. Sorption isotherms were obtained with three soil:solution ratios

$21(0.005,0.25,2 \mathrm{~kg} / \mathrm{L})$ at $\mathrm{pH} 4.5$. The initial solution $\mathrm{U}(\mathrm{VI})$ concentrations equilibrated with soils

22 were $0.5,0.9,1.8,3.3,5.0,6.0,12,20,30,50,75$, and $120 \mu \mathrm{M}$. Each soil-solution mixture was

23 shaken for 4 days prior to sampling. 
2 For all batch sorption experiments, the samples equilibrated on a reciprocating shaker table for

3 the desired reaction time. Sacrificial samples were collected by rapid centrifugation $(1500 \times g$

4 for 4 minutes). The supernatant was subsequently filtered ( $0.2 \mu \mathrm{m}$ polysulfone filter), acidified

5 to $\mathrm{pH}<2$ with concentrated $\mathrm{HNO}_{3}$ and stored at $4{ }^{\circ} \mathrm{C}$ until analysis by kinetic phosphorescence

6 analysis (KPA; Chemchek Instruments, city, WA). Uranium sorbed by the soil was calculated

7 from the change in solution concentration. Two types of blank samples were run in parallel with

8 the experimental replicates: 1) soil samples with no added $\mathrm{U}(\mathrm{VI})$ to quantify any naturally

9 occurring $\mathrm{U}$ released by the soil (Table 1), and 2) samples with no soil to detect any U(VI) lost

10 by contact with labware. All samples and controls were run in triplicate.

\section{2.2.2. Transport Experiments}

14 Crushed and sieved $(<2 \mathrm{~mm})$ saprolite was wet packed in a glass chromatography column $(1 \mathrm{~cm}$

15 inner diameter) to a final bed length of $3 \mathrm{~cm}$. The column was flushed with $0.05 \mathrm{M} \mathrm{NaNO}_{3}(\mathrm{pH}$

$164.5)$ at a specific discharge of $1.22 \mathrm{~cm} / \mathrm{h}$. Using the same flow rate, the influent solution was

17 changed to $10 \mu \mathrm{M} \mathrm{U}(\mathrm{VI})$ plus $5 \mathrm{mM} \mathrm{NaBr}$ in $0.045 \mathrm{M} \mathrm{NaNO}_{3}$, $\mathrm{pH} 4.5$, maintaining constant

18 ionic strength throughout the experiment. After the desired breakthrough period, the inlet

19 solution was switched back to a $\mathrm{U}(\mathrm{VI})$-free, $0.05 \mathrm{M} \mathrm{NaNO}_{3}$ solution. Effluent samples were

20 collected with a fraction collector and effluent $\mathrm{pH}$ was measured. Samples for $\mathrm{U}$ analysis were

21 acidified $(\mathrm{pH}<2)$ with concentrated nitric acid and stored at $4^{\circ} \mathrm{C}$ until analysis by KPA.

22 Bromide concentration in the effluent was measured by ion chromatography (IC). 
1 As a check for nonequilibrium effects, either physical or chemical, during the desorption phase

2 of the experiment a flow interrupt manipulation was conducted after $\sim 810$ pore volumes $(\sim 57$

3 days; (BRUSSEAU et al., 1997). After 40 hrs of flow interruption (equivalent to 24 pore

4 volumes), the injection of $\mathrm{U}(\mathrm{VI})$-free solution continued until the effluent $\mathrm{U}$ concentration

5 reached zero. Mass balance for uranium and bromide was calculated by integrating the area

6 under the measured breakthrough curves; $105 \pm 5 \%$ of the injected uranium was recovered in the

7 column effluent.

$9 \quad 2.3$ Modeling

11 For clarity we reserve use of the terms "optimize" or "fit(ting)" to indicate that the value of one

12 or more model parameters was adjusted to improve the model description of the data. The terms

13 "simulation" or "prediction" indicate that the value of each model parameter was fixed to a

14 specified value during the model run. Model simulations that were conducted using the reaction

15 network and parameter values for U sorption reported by Waite et al. (1994) will be referred to

16 as the Waite model for simplicity.

$18 \quad$ 2.3.1 Batch Equilibrium Modeling

19 Uranium sorption (edges, isotherms, and kinetics) onto saprolite was modeled using a two-site

20 surface complexation model (BARNETT et al., 2000; WAITE et al., 1994) that assumes a small

21 number of high affinity (strong) sites and a larger number of lower affinity (weak) sites. The

22 total number of sorbing sites is assumed to be proportional to the DCB extractable Fe content of

23 the soil ( 0.875 mole sites/mole Fe). Model simulations were conducted using the surface 
1 complexation parameters reported by Waite et al. (1994). In addition, the model was fit to the

2 data by optimizing the value of specified parameters as described below. Formation constants

3 for U(VI) aqueous species were obtained from the NEA compilation (GRENTHE et al., 1992;

4 GuillaumONT et al., 2003).

6 Model simulations of sorption edges and isotherms and fitting to the $\mathrm{R}_{\mathrm{s} / \mathrm{w}} 0.005$ sorption edge

7 results were performed using FITEQL 4.0 (HERBELIN and WESTALL, 1999). Optimized

8 parameter estimates were obtained using only the results from the $\mathrm{R}_{\mathrm{s} / \mathrm{w}}=0.005$ treatment by the

9 following procedure. Using the data where $\mathrm{pH}<6$, the proportion of strong:weak sites was

10 varied to locate the minimum value of the goodness-of-fit indicator, the sum of squares divided

11 by the degrees of freedom (SOS/DF). In this $\mathrm{pH}$ range, under ambient air, carbonate aqueous

12 and surface complexes have a minor impact on model-predicted U speciation. Using the optimal

13 value of strong sites obtained from this procedure $(1.02 \pm 0.02 \mathrm{mmole}$ strong sites/ mole $\mathrm{Fe})$ the

14 model was fit to the $\mathrm{pH}<6$ data by adjusting the value of the surface complexation constants for

15 the reactions:

16

17

18

19

21 where $\mathrm{UO}_{2}{ }^{2+}$ is a uranium species in the liquid phase, and $\equiv \mathrm{Fe}_{\mathrm{s}}(\mathrm{OH})_{2}$ and $\equiv \mathrm{Fe}_{\mathrm{w}}(\mathrm{OH})_{2}$ are strong

22 and weak $\mathrm{pH}$-dependent binding sites, respectively. Using the optimized values for the

23 proportion of strong sites and the $\log \mathrm{K}$ 's $(\mathrm{K}=$ reaction equilibrium constant) determined for (1a) 
1 and (1b), the model was fit to the data for $\mathrm{pH}>6$ by adjusting the value of the surface

2 complexation constant for the reactions:

$$
\left(\equiv \mathrm{Fe}_{\mathrm{w}}(\mathrm{OH})_{2}\right)+\mathrm{UO}_{2}^{2+}+\mathrm{CO}_{3}^{2-}=\left(\equiv \mathrm{Fe}_{\mathrm{w}} \mathrm{O}_{2}\right) \mathrm{UO}_{2} \mathrm{CO}_{3}^{2-}+2 \mathrm{H}^{+}
$$

This final optimized parameter set was used to predict the $U$ sorption edge for the $R_{\mathrm{s} / \mathrm{w}}=0.25$

9 and $\mathrm{U}$ sorption isotherms for all three $\mathrm{R}_{\mathrm{s} / \mathrm{w}}$ values. Our optimized parameter set was also used to 10 predict $\mathrm{U}$ transport for the column experiment.

\section{$12 \quad$ 2.3.2 Batch Kinetic Modeling}

13 The sorption kinetics data were modeled using a kinetic version of the surface complexation

14 model that assumes sorption occurs simultaneously onto high and low affinity sites. The model

15 included all aqueous and surface complexation reactions used in the equilibrium model. The $\mathrm{U}$

16 sorption reactions indicated by (1a) and (1b) were assumed to be the most kinetically limited.

17 Model calculations were performed with the biogeochemical reaction model HydroGeoChem

18 (HGC) v5.0 (YEH et al., 2004) that allows any combination of equilibrium and user-defined

19 kinetic reactions. Forward and backward rate constants $\left(\mathrm{k}_{\mathrm{f}}\right.$ and $\mathrm{k}_{\mathrm{b}}$, respectively) for reactions ( $\left.1 \mathrm{a}\right)$

20 and (1b) were estimated with the nonlinear parameter estimation program PEST (DOHERTY,

21 2002). All other model parameters (site density, equilibrium constants) were independently

22 determined as described above and fixed during the rate coefficient inversion process. We

23 attempted to fit the model to the kinetic data first by fixing the ratio of rate constants to be equal 
1 to the independently determined equilibrium constants for the corresponding reactions and,

2 second, by allowing the ratio $\mathrm{k}_{\mathrm{f}}: \mathrm{k}_{\mathrm{b}}$ to vary.

$4 \quad$ 2.3.3 Transport Modeling

6 Uranium(VI) transport was predicted using the reaction based modeling approach incorporated

7 in HydroGeoChem (HGC) v5.0. The model decouples fast and slow reactions, which enables

8 robust numerical integration (YEH et al., 2004). Two simulations were performed, the first using

9 the calibrated parameter values derived from our batch experiment, and the second using

10 parameters reported by Waite et al. (1994).

\section{3. RESULTS AND DISCUSSION}

\section{3.1. Batch Experiments}

\subsubsection{Sorption Edges}

17 To investigate the effect of $\mathrm{pH}$ on $\mathrm{U}(\mathrm{VI})$ sorption, batch experiments were carried out at $\mathrm{pH}$

18 values in the range $\sim 3.5$ to 9.5 using two values of $\mathrm{R}_{\mathrm{s} / \mathrm{w}}(0.005$ and 0.25$)$ and total $\mathrm{U}$

19 concentration of $4.2 \mu \mathrm{M}$. At the lower $\mathrm{R}_{\mathrm{s} / \mathrm{w}} \mathrm{U}(\mathrm{VI})$ sorption increased sharply over a $\mathrm{pH}$ range of

204 to 6 , then decreased at $\mathrm{pH}>7.5$ (Figure 1). Such sorption envelopes have been described for

21 other solutes, and specifically U(VI), by other investigators (BARNETT et al., 2000; HINGSTON et

22 al., 1967; TRIPATHI, 1984; WAITE et al., 1994; WAZNE et al., 2003). Decreased U(VI) sorption at

23 alkaline $\mathrm{pH}$ results from the increased carbonate concentrations with increased $\mathrm{pH}$ resulting in 
1 the formation of stable aqueous uranyl-carbonate complexes. For that reason, there is an

2 increase in the estimated proportion of sorbed $\mathrm{U}$ attributed to surface uranyl-carbonate species

3 with increasing $\mathrm{pH}$ (upper panel, Figure 1; equations $2 \mathrm{a}$ and $2 \mathrm{~b}$ ). Similar features are observed

4 in the data collected at the higher $\mathrm{R}_{\mathrm{s} / \mathrm{w}}$ with some notable exceptions (Figure 1). Virtually all the

$5 \mathrm{U}(\mathrm{VI})$ sorbed over the experimental $\mathrm{pH}$ range. The edge positions where $\mathrm{U}$ sorption increased

6 and then decreased were shifted to lower and higher $\mathrm{pH}$, respectively, at the higher solids

7 concentration. Waite et al. (1994) reported a similar result for U(VI) sorption onto ferrihydrite

8 with increasing $R_{\mathrm{s} / \mathrm{w}}$. A decrease in aqueous $\mathrm{U}(\mathrm{VI})$ concentration with increased $\mathrm{R}_{\mathrm{s} / \mathrm{w}}$ suggests

9 that sorption reactions, rather than precipitation, controlled $\mathrm{U}(\mathrm{VI})$ concentration as the addition

10 of more sorbent would not be expected to change the equilibrium solubility of an $\mathrm{U}$ solid phase.

12 The surface complexation model reaction network proposed by Waite et al. (1994) was fit to the

13 experimental data for $\mathrm{R}_{\mathrm{s} / \mathrm{w}}=0.005$ by adjusting the ratio of strong sites: total sites and the

14 stability constants for the reactions described by equations (1) and (2). The calibrated model

15 described the observed data well (final $\mathrm{SOS} / \mathrm{DF}=0.13$ ), capturing the general trends in the data

16 as well as the extent of sorption over a broad $\mathrm{pH}$ range (Figure 1). In addition, the optimized

17 parameter set provided a good prediction of $\mathrm{U}(\mathrm{VI})$ sorption behavior at the $\mathrm{R}_{\mathrm{s} / \mathrm{w}}=0.25$ (Figure 1).

18 In contrast, the Waite model over-predicted $\mathrm{U}(\mathrm{VI})$ sorption for $\mathrm{R}_{\mathrm{s} / \mathrm{w}}=0.005$. At $\mathrm{pH}$ values $<6$

$19 \mathrm{U}(\mathrm{VI})$ sorption in the model is predominantly due to the strong and weak surface species

$20\left(\equiv \mathrm{FeO}_{2}\right) \mathrm{UO}_{2}$ (Eq. 1). The higher amount of sorption predicted by the Waite model is primarily

21 due to the larger fraction of strong:total sites used in that model as the formation constants for

22 these complexes are similar for both models (Table 2). As the $\mathrm{pH}$ increases, $\mathrm{U}(\mathrm{VI})$ sorption in

23 the model is increasingly due to the $\left(=\mathrm{FeO}_{2}\right) \mathrm{UO}_{2} \mathrm{CO}_{3}{ }^{2-}$ complexes (Eq. 2). Larger formation 
1 constants for these species in the Waite model account for over-predictions of U(VI) sorption at

2 higher $\mathrm{pH}$.

4 3.1.3. Sorption Isotherms

6 Sorption isotherms were established over a range of initial $U(V I)$ concentrations and three $R_{s / w}$

7 values. All the $\mathrm{U}(\mathrm{VI})$ sorption isotherms were nonlinear and did not exhibit a trend toward an 8 asymptote of maximum sorption, conforming well to the empirical Freundlich isotherm equation

9 (Figure 2). Nonlinear sorption described by the Freundlich equation has been attributed to a

10 decreasing affinity between sorbent and sorbate with an increasing extent of adsorption (SPOSITO,

11 1984). Nonlinear sorption isotherms are also described by surface complexation theory (STUMM

12 and Morgan, 1996) due to the finite number of sites available for solute sorption and the

13 specification of sites of different affinity in some representations of surface complexation models.

15 Uranium sorption onto the saprolite was similar for $\mathrm{R}_{\mathrm{s} / \mathrm{w}}=0.005$ and 0.25 but decreased at the

16 highest $\mathrm{R}_{\mathrm{s} / \mathrm{w}}=2$ (Figure 2a). These results are indicative of a solids-concentration effect in

17 which solute sorption decreases with increasing sorbent concentration. Other investigators have

18 reported experimental data (DITORO et al., 1986; HONEYMAN and SANTSCHI, 1988; OSCARSON

19 and Hume, 1998) and modeling studies (PHILLIPPI et al., 2007) that show a solids-concentration

20 effect. McKinley and Jenne (MCKINLEY and JENNE, 1991) found no such effect using $\mathrm{R}_{\mathrm{s} / \mathrm{w}}$ in the

21 range 0.0000445 to 0.00445 (assuming the ferrihydrite they used had the formula $\mathrm{Fe}_{2} \mathrm{O}_{3} \cdot \mathrm{H}_{2} \mathrm{O}$

22 (DZOMBAK and MoREL, 1990)) and suggested that when reported it was the result of

23 experimental or data reduction errors. Nevertheless, when their recommended data reduction is 
1 applied to our results, the solids-concentration effect remains evident. Additionally, when results

2 from the last sampling times of the kinetic experiments (independently derived data) are plotted

3 on the isotherms (Figure 2b, c, d), the same apparent dependence of $U$ sorption on $R_{s / w}$ remains

4 suggesting that neither experimental nor data reduction errors underlie this observation.

6 The surface complexation model that was calibrated with the $\mathrm{R}_{\mathrm{s} / \mathrm{w}} 0.005$ sorption edge data

7 adequately predicted the general trends in the observed isotherms (Figure 2) but did not capture

8 the solids-concentration effect. The solids-concentration effect results from strong interactions

9 in multicomponent systems, e.g. between $\mathrm{U}(\mathrm{VI})$, carbonate, and sorption sites (PHILLIPPI et al.,

10 2007). At the $\mathrm{pH}$ of these experiments (4.4-4.7) carbonate is a minor component. The inability

11 of the model to reproduce this effect suggests that other, as yet unidentified, reactions are absent

12 from the reaction network constituting the surface complexation model. Only the $\left(=\mathrm{FeO}_{2}\right) \mathrm{UO}_{2}$

13 (Eq 1) species are important surface complexes at the isotherm $\mathrm{pH}$ values (Figure 1). For the

14 lowest $\mathrm{R}_{\mathrm{s} / \mathrm{w}}$ our calibrated model also generally captured the amount of sorption and showed the

15 biggest discrepancy with the Waite model (Figure 2a). The curvature for both models at

$16 \log \left(\mathrm{C}_{\mathrm{eq}}\right)\left(\right.$ where $\mathrm{C}_{\mathrm{eq}}=$ final equilibrium aqueous-phase $\mathrm{U}$ concentration $)=-7$ to -6 reflects

17 saturation of strong (high affinity) binding sites and the transition to sorption onto weak sites, a

18 feature not reflected in the data. Our model, with fewer strong sites (Table 2), predicts earlier

19 strong site saturation and departure from the Waite model. The ratio of strong sites to total

20 uranium increased with increasing $\mathrm{R}_{\mathrm{s} / \mathrm{w}}$, consequently the saturation feature becomes less

21 prominent as the model predicts sorption to occur predominantly on a single site $\left(\left(\equiv \mathrm{Fe}_{\mathrm{s}} \mathrm{O}_{2}\right) \mathrm{UO}_{2}\right)$

22 and the two model predictions become more similar (Figure 2) as expected given the similarity

23 of their parameter values (Table 2). For comparison, results from the final sampling time of the 
1 kinetic experiments (see below) are plotted on the isotherm plots and show good agreement with

2 the isotherm data. We take this as indication that the 4 day equilibration period for the edge and

3 isotherm experiments was sufficient.

4

5 Overall, the ability of both models to predict the general trends in the sorption isotherms was

6 acceptable. The results from the model predictions are encouraging given that the calibration

7 data, obtained at discrete $\mathrm{pH}$ values and constant total $\mathrm{U}$ in the sorption edge experiments,

8 represent a single point in an isotherm experiment conducted at constant $\mathrm{pH}$ and variable total $\mathrm{U}$.

9 Both models overpredicted $\mathrm{U}$ sorption as the $\mathrm{R}_{\mathrm{s} / \mathrm{w}}$ increased and the magnitude of the error

10 increased with $\mathrm{R}_{\mathrm{s} / \mathrm{w}}$. Model failure of this kind would lead to the expectation that $\mathrm{U}$ is less

11 mobile in the environment than the isotherm data would indicate.

\section{3.1.1. Kinetic Experiments}

15 In addition to preliminary scoping experiments conducted to guide the choice of reaction time for

16 the equilibrium experiments, a more detailed set of kinetic experiments was performed using

17 three $\mathrm{R}_{\mathrm{s} / \mathrm{w}}$ and two $\mathrm{C}_{0}$ values. Uranium loss from solution exhibited a faster phase with $80 \%$ loss

18 from solution occurring in less than eight hours, and a slower phase during which the reaction

19 approached steady state over the next seven days (Figure 3). The rate of $\mathrm{U}$ loss from solution

$20(\mu \mathrm{mole} / \mathrm{L} / \mathrm{h})$ increased with increasing $\mathrm{R}_{\mathrm{s} / \mathrm{w}}$ at both $\mathrm{C}_{0}$ values to the extent that at the highest $\mathrm{R}_{\mathrm{s} / \mathrm{w}}$

21 the reaction was $>99 \%$ complete within 15 minutes. 
1 Two-phase sorption kinetics has been previously reported for numerous solutes and specifically

2 for U (BARNETT et al., 2000; HSI and LANGMUIR, 1985; WAITE et al., 1994). Investigators have

3 attributed this behavior to a variety of mechanisms including distribution of site affinities,

4 sorption onto outer versus internal surfaces (i.e., diffusion limitation), or fast initial sorption

5 followed by slow structural rearrangement or recrystallization (BARROw et al., 1989; DAVIS et al.,

6 1987; Evans and JuRINAK, 1976; Fuller and Davis, 1987; HARTER, 1991; SElim and

7 AMACHER, 1988). The nature of the data collected does not permit us to distinguish among these

8 possible mechanisms. To maintain a consistent modeling approach, the surface complexation

9 model used to model the equilibrium results was fit to the kinetic data by assuming the reactions

10 represented by Eq (1) to be rate limiting. Modeling results from the equilibrium experiments

11 indicated that the uranyl-carbonate surface complexes (Eq 2) were of minor importance and

12 these were maintained as equilibrium reactions in the kinetic model. To be consistent with the

13 results of the equilibrium modeling, we initially attempted to fit the model to the kinetic data by

14 fitting the forward rate constants and estimating the backward rate constants by assuming the

15 ratio of rate constants to be equal to the fitted equilibrium model formation constants. This

16 approach generally resulted in poor model fits to the data (Figure 3; Table 3). Adjusting all four

17 rate constants to fit the model to the data (i.e., allowing the rate constant ratio to vary) provided a

18 significantly better fit for five out of the six cases (Table 3). However, the resulting rate constant

19 ratios were not close to the equilibrium formation constants for either our model or Waite's

20 model. The two parameter model was satisfactory for the conditions that most closely

21 approximated the column transport experiment $\left(\mathrm{R}_{\mathrm{s} / \mathrm{w}}=2 ; \mathrm{C}_{0}=10 \mu \mathrm{M}\right.$; Figure 3b; Table 3).

23 3.2. Transport Experiment 
2 The ability of the surface complexation model to predict U(VI) transport was tested by packing a

3 column with the same solid phase material that was used for the batch equilibrium and kinetic

4 experiments. The packing materials were not compacted to mimic the porosity of the materials

5 in the field to minimize occlusion of sorption sites and because prior experience with these

6 clayey materials has shown that compaction results in a column of such low permeability as to

7 make a transport experiment impractical. The final column contained $2.48 \mathrm{~g}$ of solids in a total

8 volume of $2.45 \mathrm{~cm}^{3}$ with a porosity of 0.66 yielding an $\mathrm{R}_{\mathrm{s} / \mathrm{w}}$ for the column of 1.5 and, at the

9 measured volumetric flow rate $\left(0.97 \mathrm{~cm}^{3} / \mathrm{h}\right)$, a fluid residence time of 1.7 hours. The influent

$10 \mathrm{U}(\mathrm{VI})$ concentration was $10 \mu \mathrm{M}$. Results of the preceding kinetic and equilibrium sorption

11 experiments led to the expectation that kinetic sorption reactions would not be important (Figure

$123 b$ ) and that the equilibrium sorption model, calibrated only from the sorption edge at $\mathrm{R}_{\mathrm{s} / \mathrm{w}}=$

130.005 , would predict less U(VI) sorption (i.e., earlier breakthrough) than would be observed

14 (Figure $2 \mathrm{~b}, \log \left(\mathrm{C}_{\mathrm{eq}}\right)=-5$ ). Each of these expectations was tested in the transport experiment.

16 Transport of the nonreactive bromide tracer was faster than that of U(VI) as expected, reaching

17 complete breakthrough (relative concentration, $\left.\mathrm{C} / \mathrm{C}_{0},=1\right)$ within 1.4 pore volumes $(\mathrm{PV})($ Figure

18 4). A dispersion coefficient $\left(D, \mathrm{~L}^{2} / \mathrm{T}\right)$ for the experiment was determined by fitting the standard

19 convective-dispersive equation to the bromide data using CXTFIT (PARKER and

20 VANGENUCHTEN, 1984) and assuming a retardation factor equal to one. The optimal value of $D$

21 was $0.059 \pm 0.006 \mathrm{~cm}^{2} / \mathrm{h}$ yielding a column Peclet $(P e)$ number of $102 \pm 10(P e=v L / D ; v=$

22 average linear porewater velocity $(\mathrm{cm} / \mathrm{h}) ; L=$ column length $(\mathrm{cm}) ; D=$ dispersion coefficient

$\left.23\left(\mathrm{~cm}^{2} / \mathrm{h}\right)\right)$, which is indicative of advection-dominated mass transport. 
2 In contrast to bromide, uranium transport through the column was significantly retarded, first

3 appearing in the column effluent at $105 \mathrm{PV}$ with complete breakthrough $\left(\mathrm{C} / \mathrm{C}_{0}=1\right)$ achieved

4 after $\sim 161 \mathrm{PV}$ (Figure 4). Uranium injection continued for an additional 454 pore volumes at

5 which time the influent was switched to bromide- and $\mathrm{U}(\mathrm{VI})$-free $0.05 \mathrm{M} \mathrm{NaNO}_{3}$. Bromide

6 washout was essentially a mirror image of the breakthrough curve (BTC) and was not detected in

7 the effluent after $1.5 \mathrm{PV}$ of the washout phase; $99 \pm 1 \%$ of bromide was recovered in the column

8 effluent.

10 Uranium washout from the column took much longer than bromide and exhibited pronounced

11 tailing. Whereas $\mathrm{U}$ breakthrough was achieved over a span of $56 \mathrm{PV}$, U washout required nearly

$12880 \mathrm{PV}$ (Figure 4). The mechanism responsible for $\mathrm{U}$ retention on the solids was reversible as

$13105 \pm 5 \%$ of the injected U was recovered in the effluent. Solute breakthrough curves with

14 sharp fronts and tailing during washout can result from nonlinear equilibrium sorption isotherms.

15 Time-dependent phenomena (chemical or physical nonequilibrium) can also produce tailing.

16 Several characteristics of the data suggest that rate-limited processes were not responsible for the

17 observed U tailing. Physical nonequilibrium (e.g., diffusion into aggregates) should impact the

18 nonreactive bromide tracer as well as U, yet the observed Br BTC did not exhibit early

19 breakthrough or tailing on either the ascending or descending limbs. Numerical simulations of

20 rate-limited sorption show that, for linear sorption isotherms, the same tailing profile is apparent

21 during breakthrough and washout, i.e., as the relative concentration approaches 1 and 0 ,

22 respectively (BRUSSEAU et al., 1997; SELIM et al., 1990). When the underlying isotherm is

23 nonlinear similar, but not identical, tailing is evident in the breakthrough and washout (SELIM et 
1 al., 1990). The uranium breakthrough curve (ascending limb) exhibited tailing; a relative

2 concentration of 0.5 was reached over a span of 21 pore volumes, the rise from $\mathrm{C} / \mathrm{C}_{0}=0.5$ to 1

3 required $\sim 35$ pore volumes. However, the breakthrough tailing was minor by comparison and

4 not similar to that observed for the washout portion. Finally, results of the batch sorption kinetic

5 experiments suggested that the sorption reaction would largely be complete within the 1.7 hour

6 fluid residence time and kinetics should not affect U breakthrough (Figure 3b). Although our

7 sorption results cannot be used to infer a characteristic time frame for desorption, other

8 investigators have reported the rapid ( $<1$ hour) desorption of U(VI) from goethite even after 6.5

9 months aging (GIAMMAR and HERING, 2001).

11 As a direct test for time-dependent processes affecting the $\mathrm{U}$ breakthrough curve we conducted a

12 flow interrupt manipulation during the washout portion of the transport experiment. When the

13 relative $\mathrm{U}$ concentration in the effluent reached $\sim 0.25$ the pump was stopped for 40 hours

14 (equivalent to 23.5 pore volumes). If nonequilibrium processes were controlling the release of $U$,

15 we anticipated that when flow resumed $U$ concentration in the effluent would be higher than

16 before the interrupt. Immediately following the flow interrupt we measured a small but

17 statistically insignificant decrease in $U$ concentration (Figure 4, inset). The short duration and

18 small magnitude of the perturbation suggest that nonequilibrium processes do not exert a

19 significant influence on $\mathrm{U}$ transport for this experiment.

21 Uranium transport simulations were performed by incorporating the surface complexation

22 reaction network into the multicomponent reactive transport code HydroGeoChem (HGC) v. 5.0

23 (YEH et al., 2004). For the simulations, the column was discretized with 20 nodes and 4 equal 
1 size elements $(0.886 \mathrm{~cm} \times 0.886 \mathrm{~cm} \times 0.779 \mathrm{~cm}$ each $)$. The dispersion coefficient was

2 determined from the bromide breakthrough curve as described above. The simulation was

3 performed for a total duration of 2500 hours ( 1490 PV) with a constant time-step size of 0.1

4 hour. Further details on the model, its capabilities, and implementation can be found in Zhang et

5 al. (ZHANG et al., 2007). All reactions were assumed to be equilibrium reactions (i.e., no kinetic

6 limitations). The flow interrupt was not included as part of the transport simulations. Two

7 transport simulations were performed, one using the model parameter values optimized to the

$8 \mathrm{R}_{\mathrm{S} / \mathrm{w}} 0.005$ sorption edge results and the second using the parameter values reported by Waite et

9 al. (1994).

11 Our optimized parameter set predicted uranium breakthrough that occurred at $\sim 26 \mathrm{PV}$, nearly 80

12 pore volumes earlier than observed; simulated $\mathrm{U}(\mathrm{VI})$ washout was also more rapid than observed.

13 This result was expected given that the same model underpredicted $\mathrm{U}(\mathrm{VI})$ sorption in the

14 equilibrium isotherms (Figure 2b). Transport simulations using Waite's parameters provided a

15 much better prediction of the U(VI) BTC which was unexpected as this model overpredicted

$16 \mathrm{U}(\mathrm{VI})$ sorption isotherms for all conditions. As for the isotherms, the difference in the two

17 models is related to the difference in the estimated number of strong sites. The underlying

18 reason why Waite's parameter set was able to predict U(VI) transport remains unclear.

\section{4. SUMMARY AND CONCLUSIONS}

22 Batch and column experiments were conducted to investigate $\mathrm{U}(\mathrm{VI})$ sorption onto and transport

23 through saprolite derived from interbedded shale, limestone, sandstone sequences. A surface 
1 complexation model was calibrated to our data and subsequently used to predict sorption

2 equilibria, kinetics, and transport. Although prediction of batch experiments using our calibrated

3 model generally performed as well as or better than model predictions using Waite's parameter

4 set it was inferior predicting $\mathrm{U}(\mathrm{VI})$ transport. The reaction network constituting the surface

5 complexation model could not reproduce a solids-concentration effect evident in the data. This

6 may be due to the fact that most batch-type laboratory experiments employ low solid:solution

7 ratios where the effect is not seen. Consequently the models developed to describe these results

8 do not include the requisite reactions.

10 The transport of $\mathrm{U}(\mathrm{VI})$ through the packed column was significantly retarded, reaching $\mathrm{C} / \mathrm{C}_{0}=1$

11 at approximately $300 \mathrm{PV}$. During the washout phase of the experiment U exhibited prolonged

12 tailing, which is typical for solutes with a nonlinear sorption isotherm. Although the model

13 using optimized parameters was arguably better than Waite's model in describing the sorption

14 edge and comparable in describing the isotherms, Waite's sorption model provided a much better

15 prediction of $\mathrm{U}$ transport. This discrepancy in the transport predictions is related to differences

16 in the estimated concentration of strongly sorbing sites a parameter that, to date, is an adjustable

17 parameter in model fitting rather than a directly measured quantity.

19 Ideally, batch sorption experiments can be used to make predictions about solute transport.

20 Recent papers suggest that surface complexation modeling is now mature enough to enable the

21 blind prediction of solute sorption behavior (RICHTER et al., 2005a; RICHTER et al., 2005b). The

22 results presented in this study for $\mathrm{U}(\mathrm{VI})$ highlight the challenges that remain in defining correct

23 conditions for batch-type experiments (e.g., solid to solution ratio), the development of the 
1 reaction networks used to describe those experiments and used to parameterize transport models,

2 and also underline a gap in our ability to transfer batch results to transport simulations.

5 Acknowledgements. This work was funded by the U.S. Department of Energy, Office of

6 Science, Office of Biological and Environmental Research, Subsurface Biogeochemical

7 Research Program. The authors would like to thank two anonymous reviewers for their

8 comments. This manuscript has been authored by UT-Battelle, LLC, under contract DE-AC05-

9 00OR22725 with the U.S. Department of Energy. The United States Government retains and the

10 publisher, by accepting the article for publication, acknowledges that the United States

11 Government retains a non-exclusive, paid-up, irrevocable, world-wide license to publish or

12 reproduce the published form of this manuscript, or allow others to do so, for United States

13 Government purposes.

14

15 
Allard T., Ildephonse P., Beaucaire C., and Calas G. (1999) Structural chemistry of uranium associated with $\mathrm{Si}, \mathrm{Al}$, and $\mathrm{Fe}$ gels in a granitic uranium mine. Chem. Geol. 158, 81-103.

Arnold T., Zorn T., Zanker H., Bernhard G., and Nitsche H. (2001) Sorption behavior of U(VI) on phyllite: experiments and modeling. J. Contam. Hydrol. 47, 219-231.

Bargar J. R., Reitmeyer R., and Davis J. A. (1999) Spectroscopic confirmation of uranium(VI)carbonato adsorption complexes on hematite. Environ. Sci. Technol. 33(14), 2481-2484.

Barnett M. O., Jardine P. M., and Brooks S. C. (2002) U(VI) adsorption to heterogeneous subsurface media: Application of a surface complexation model. Environ. Sci. Technol 36(5), 937-942.

Barnett M. O., Jardine P. M., Brooks S. C., and Selim H. M. (2000) Adsorption and transport of U(VI) in subsurface media. Soil Sci. Soc. Am. J. 64(3), 908-917.

Barrow N. J., Gerth J., and Brummer G. W. (1989) Reaction kinetics of the adsorption of nickel, zinc, and cadmium by goethite: II. Modeling the extent and rate of reaction. J. Soil Sci. 40, 437-450.

Brusseau M. L., Hu Q., and Srivastava R. (1997) Using flow interruption to identify factors causing nonideal contaminant transport. J. Contam. Hydrol. 24, 204-219.

Combes J. M., Chisholm-Brause C. J., Brown G. E., Parks G. A., Conradson S. D., Eller P. G., Triay I. R., Hobart D. E., and Meijer A. (1992) EXAFS spectroscopic study of neptunium(V) sorption at the $\alpha-\mathrm{FeOOH}$ water interface. Environ. Sci. Technol. 26, 376382.

Davis J. A., Fuller C. C., and Cook A. D. (1987) A model for trace metal sorption processes at the calcite surface: Adsorption of $\mathrm{Cd}^{2+}$ and subesquent solid solution formation. Geochim. Cosmochim. Acta 51, 1477-1490.

DiToro D. M., Mahoney J. D., Kirchgraber P. R., O'Byrne A. L., Pasquale L. R., and Piccirilli D. C. (1986) Effects of nonreversibility, particle concentration, and ionic strength on heavy metal sorption. Environ Sci Technol 20, 55-61.

Doherty J. (2002) PEST: Model Independent Parameter Estimation. Watermark Numerical Computing.

Duff M. C., Coughlin J., and Hunter D. B. (2002) Uranium co-precipitation with iron oxide minerals. Geochim. Cosmochim. Acta 66, 3533-3547.

Dzombak D. A. and Morel F. M. M. (1990) Surface Complexation Modeling: Hydrous Ferric Oxide. John Wiley \& Sons.

Evans R. L. and Jurinak J. J. (1976) Kinetics of phosphate release from a desert soil. Soil Sci. 121, 205-211.

Fuller C. C. and Davis J. A. (1987) Processes and kinetics of $\mathrm{Cd}^{2+}$ sorption by a calcareous aquifer sand. Geochim. Cosmochim. Acta 51, 1491-1502.

Gambrell R. P. (1996) Manganese. In Methods of Soil Analysis. Part 3. Chemical Methods (ed. D. L. Sparks), pp. 665-682. Soil Science Society of America and American Society of Agronomy.

Gamerdinger A. P., Kaplan D. I., Wellman D. M., and Serne R. J. (2001) Two-region and ratelimited sorption of uranium(VI) during transport in an unsaturated silt loam. Water Resour. Res. 37, 3147-3153.

Giammar D. E. and Hering J. G. (2001) Time scales for sorption-desorption and surface precipitation of uranyl on goethite. Environ. Sci. Technol. 35(16), 3332-3337. 
Grenthe I., Fuger J., Konings R. J. M., Lemire R. J., Muller A. B., Gregu C. N.-T., and Wanner H. (1992) Chemical Thermodynamics 1: Chemical Thermodynamics of Uranium. NorthHolland Elsevier Science.

Guillaumont R., Fanghanel T., Neck V., Fuger J., Palmer D. A., Grenthe I., and Rand M. H. (2003) Update on the Chemical Thermodynamics of Uranium, Neptunium, Plutonium, Americium, and Technetium. Elsevier.

Harter R. D. (1991) Kinetics of sorption/desorption processes in soil. In Rates of Soil Chemical Processes, Vol. 27 (ed. D. L. Sparks and D. L. Suarez), pp. 135-149. Soil Science Society of America.

Hendershot W. H. and Duquette M. (1986) A simple barium chloride method for determining cation exchange capacity and exchangeable cations. Soil Sci. Soc. Am. J. 50, 605-608.

Herbelin A. and Westall J. (1999) FITEQL: A Computer Program for Determination of Chemical Equilibrium Constants from Experimental Data. Department of Chemistry, Oregon State University.

Hingston F. J., Atkinson R. J., Posner A. M., and Quirk J. P. (1967) Specific adsorption of anions. Nature 215, 1459-1461.

Honeyman B. D. and Santschi P. H. (1988) Metals in Aquatic Systems. Environmental Science \& Technology 22(8), 862-871.

Hsi C. K. D. and Langmuir D. (1985) Adsorption of uranyl into ferric oxyhydroxides: Application of the surface complexation site-binding model. Geochim. Cosmochim. Acta 49, 1931-1941.

Jardine P. M., Wilson G. V., and Luxmoore R. J. (1990) Unsaturated solute transport through a forest soil during rain events. Geoderma 46, 103-118.

Kohler M., Curtis G. P., Kent D. B., and Davis J. A. (1996) Experimental investigation and modeling of uranium (VI) transport under variable chemical conditions. Water Resour. Res. 32, 3539-3551.

Kohler M., Wieland E., and Leckie J. O. (1992) Metal-ligand-surface interactions during sorption of uranyl and neptunyl on oxides and silicates. In Water-Rock Interactions (ed. Y. K. Kharaka and A. S. Maest). Balkema.

Li K., Amoozegar A., Robarge W. P., and Buol S. W. (1997) Water movement and solute transport through saprolite. Soil Sci. Soc. Am. J. 61, 1738-1745.

Loeppert R. H. and Inskeep W. P. (1996) Iron. In Methods of Soil Analysis. Part 3. Chemical Methods (ed. D. L. Sparks), pp. 639-664. Soil Science Society of America and American Society of Agronomy.

Mayes M. A., Jardine P. M., Mehlhorn T. L., Bjornstad B. N., and Zachara J. M. (2003) Transport of multiple tracers in variably saturated humid region structured soils and semiarid region laminated sediments. J. Hydrol. 275, 141-161.

McKinley J. P. and Jenne E. A. (1991) Experimental investigation and review of the "solid concentration" effect in adsorption studies. Enviorn. Sci. Technol. 25, 2082-2087.

McKinley J. P., Zachara J. M., Smith S. C., and Turner G. D. (1995) The influence of uranyl hydrolysis and multiple site-binding reactions on adsorption of U(VI) to montmorillonite. Clays Clay Min. 43(5), 586-598.

Morrison S. J., Spangler R. R., and Tripathi V. S. (1995) Adsorption of uranium(VI) on amorphous ferric oxyhydroxide at high concentrations of dissolved carbon(IV) and sulfur(VI). J. Cont. Hydrol. 17, 333-346. 
Morse J. W., Shanbhag P., Saito A., and Choppin G. R. (1984) Interaction of uranyl ions in carbonate media. Chem. Geol. 42, 85-99.

Moyes L. N., Parkman R. H., Charnock J. M., Vaughan D. J., Livens F. R., Hughes C. R., and Braithwaite A. (2000) Uranium uptake from aqueous solution by interaction with goethite, lepidocrosite, muscovite, and mackinawite: an x-ray absorption spectroscopy study. Enviorn. Sci. Technol. 34, 1062-1068.

Oscarson D. W. and Hume H. B. (1998) Effect of the solid:liquid ratio on the sorption of $\mathrm{Sr}^{2+}$ and $\mathrm{Cs}^{+}$on bentonite. In Adsorption of Metals by Geomedia (ed. E. A. Jenne), pp. 277289. Academic Press.

Parker J. C. and vanGenuchten M. T. (1984) Determining transport parameters from laboratory column and field tracer experiments, pp. 96. Virginia Polytechnic Institute and State University.

Peech M. (1965) Lime requirement. In Methods of Soil Analysis. Part 2. Chemical and Microbiological Methods (ed. C. A. Black), pp. 927-932. American Society of Agronomy.

Phillippi J. M., Loganathan V. A., McIndoe M. J., Barnett M. O., Clement T. P., and Roden E. E. (2007) Theoretical solid/solution ratio effects on adsorption and transport: Uranium(VI) and carbonate. Soil Science Society of America Journal 71(2), 329-335.

Porro I., Newman M. E., and Dunnivant F. M. (2000) Comparison of batch and column methods for determining strontium distribution coefficients for unsaturated transport in basalt. Environ Sci Technol 34, 1679-1686.

Richter A., Brendler V., and Nebelung C. (2005a) Blind prediction of Cu(II) sorption onto goethite: Current capabilities of diffuse double layer model. Geochim. Cosmochim. Acta 69(11), 2725-2734.

Richter A., Brendler V., and Nebelung C. (2005b) The effect of parameter uncertainty on blind prediction of $\mathrm{Np}(\mathrm{V})$ sorption onto hematite using the Diffuse Double Layer Model. Radiochim. Acta 93, 527-531.

Riley R. G., Zachara J. M., and Wobber F. J. (1992) Chemical contaminants on DOE lands and selection of contaminant mixtures for subsurface science research., pp. 77. U S Department of Energy.

Selim H. M. and Amacher M. C. (1988) A second-order kinetic approach for modeling solute retention and transport in soils. Water Resour. Res. 24, 2061-2075.

Selim H. M., Amacher M. C., and Iskandar I. K. (1990) Modeling the Transport of Heavy Metals in Soils, Vol. Monograph 90-2 (ed. U. S. Army), pp. 156. Cold Regions Research and Engineering Laboratory.

Sposito G. (1984) The Surface Chemistry of Soils. Oxford University Press.

Stumm W. and Morgan J. J. (1996) Aquatic Chemistry: Chemical Equilibria and Rates in Natural Waters. John Wiley and Sons.

Ticknor K. V. (1994) Uranium sorption on geological materials. Radiochim. Acta 64, 229-236.

Tripathi V. S. (1984) Uranium(VI) transport modeling: geochemical data and submodels. Ph.D., Stanford.

Turner G. D., Zachara J. M., McKinley J. P., and Smith S. C. (1996) Surface-charge properties and $\mathrm{UO}_{2}{ }^{2+}$ adsorption of a subsurface smectite. Geochim. Cosmochim. Acta 60(18), 33993414.

Vepraskas M., Jongmans A., Hoover M., and Bouma J. (1991) Hydraulic conductivity of saprolite as determined by channels and porous groundmass. Soil Sci. Soc. Am. J. 55, 932-938. 
Waite T. D., Davis J. A., Fenton B. R., and Payne T. E. (2000) Approaches to modeling uranium(VI) adsorption on natural mineral assemblages. Radiochim. Acta 88, 687-693.

Waite T. D., Davis J. A., Payne T. E., Waychunas G. A., and Xu N. (1994) Uranium(VI) adsorption to ferrihydrite: Application of a surfce complexation model. Geochim. Cosmochim. Acta 58, 5465-5478.

Wazne M., Korfiatis G., and Meng X. (2003) Carbonate effects on Hexavalent uranium adsorption by iron oxyhydroxide. Enviorn. Sci. Technol. 37, 3619-3624.

Wersin P., Hochella M. F., Persson P., Redden G., Leckie J. O., and Harris D. (1994) Interaction between aqueous uranium(VI) and sulfide minerals: Spectroscopic evidence for sorption and reduction. Geochim. Cosmochim. Acta 58(13), 2829-2843. HYDROGEOCHEM 5.0: A three-dimensional model of coupled fluid flow, thermal transport, and hydrogeochemical transport through variable saturated conditions Version 5.0. . Oak Ridge National Laboratory.

Zhang F., Yeh G.-T., Parker J. C., Brooks S. C., Pace M. N., and Jardine P. M. (2007) A reaction-based paradigm to model reactive chemical transport in groundwater with general kinetic and equilibrium reactions. J. Contam. Hydrol. 92, 10-32.

Zhang F., Luo W., Parker J. C., Brooks S. C., Watson D. B., Jardine P. M., and Gu B. (2011) Modeling uranium transport in acidic contaminated groundwater with base addition. $J$. Hazard. Mater. 190, 863-868. 
Table 1. Physical, chemical, and mineralogical properties of saprolite.

\begin{tabular}{|c|c|}
\hline $\mathrm{pH}^{\mathrm{a}}$ & $4.27 \pm 0.02$ \\
\hline Cation Exchange Capacity & $11.3 \pm 0.3 \mathrm{cmol}_{+} / \mathrm{kg}$ \\
\hline \multicolumn{2}{|c|}{ Exchangeable Cations $\left(\mathrm{cmol}_{+} / \mathrm{kg}\right)$} \\
\hline $\mathrm{Ca}$ & $2.07 \pm 0.05$ \\
\hline $\mathrm{Mg}$ & $1.43 \pm 0.03$ \\
\hline $\mathrm{K}$ & $0.116 \pm 0.003$ \\
\hline $\mathrm{Al}$ & $3.4 \pm 0.1$ \\
\hline $\mathrm{Mn}$ & $0.0113 \pm 0.0002$ \\
\hline $\mathrm{Fe}$ & $0.0043 \pm 0.0003$ \\
\hline Exchangeable Acidity $^{\mathrm{c}}$ & $7.7 \pm 0.3 \mathrm{cmol}_{1} / \mathrm{kg}$ \\
\hline \multicolumn{2}{|l|}{ Extractable Fe } \\
\hline $\mathrm{CBD}^{\mathrm{d}}$ & $340 \pm 10 \mathrm{mmole} / \mathrm{kg}$ \\
\hline$\left(\mathrm{NH}_{4}\right)_{2} \mathrm{Oxalate}^{\mathrm{e}}$ & $11.8 \pm 0.2 \mathrm{mmole} / \mathrm{kg}$ \\
\hline Extractable $\mathrm{Mn}^{\mathrm{f}}$ & $3.3 \pm 0.1 \mathrm{mmole} / \mathrm{kg}$ \\
\hline $\mathrm{U}$ content ${ }^{\mathrm{g}}$ & $12.4 \pm 0.2 \mu \mathrm{mole} / \mathrm{kg}$ \\
\hline \multicolumn{2}{|l|}{ Mineralogy ${ }^{\mathrm{h}}$} \\
\hline Major (95\%) & $\mathrm{Qz}_{38}, \mathrm{Ill}_{30}, \mathrm{~K}-\mathrm{fd}_{27}$ \\
\hline Minor $(<5 \%)$ & HIV $>>$ Ver, Gt, Lp > Fr, Kn \\
\hline
\end{tabular}

$4 \quad{ }^{\mathrm{a}}$ Soil $\mathrm{pH}$ determined on $5 \mathrm{~g}$ of soil and $10 \mathrm{~mL} 10 \mathrm{mM} \mathrm{CaCl}_{2}$ slurry.

$5{ }^{\mathrm{b}}$ Exchangeable cations were determined using $0.1 \mathrm{M} \mathrm{BaCl}_{2}$ as an index ion (HENDERSHOT and

6 DUQuETTE, 1986). CEC = Exchangeable acidity + exchangeable cations - exchangeable Al.

$7 \quad{ }^{\mathrm{c}}$ Exchangeable acidity was measured by $\mathrm{BaCl}_{2}$ - triethanolamine (TEA) method (PEECH, 1965).

$8{ }^{\mathrm{d}}$ Citrate-bicarbonate-dithionate (CBD) extractable (total) $\mathrm{Fe}$ was conducted in an $80^{\circ} \mathrm{C}$ water

9 bath (LOEPPERT and INSKEEP, 1996).

$10{ }^{\mathrm{e}}$ Ammonium oxalate extractable (amorphous) Fe was measured after shaking $4 \mathrm{hr}$ in the dark

11 (LOEPPERT and INSKEEP, 1996).

$12 \quad{ }^{\mathrm{f}} \mathrm{NH}_{2} \mathrm{OH} \cdot \mathrm{HCl}$ extractable (total) $\mathrm{Mn}$ (GAMBRELL, 1996).

$13{ }^{\mathrm{g}}$ Total naturally occurring $\mathrm{U}$ in the saprolite. Determined by instrumental neutron activation

14 analysis, ActLabs, Tucson, AZ.

$15{ }^{\mathrm{h}}$ Abbreviation: Qz- quartz, Ill- illite, K-fd- potassium feldspar (microcline+ Orthoclase), HIV-

16 hydroxy interlayered vermiculite, Ver- vermiculite, Gt- goethite, Lp- lepidocrocite, Fr-

17 ferrihydrite, Kn- kaolinite. 
1 Table 2: Surface complexation model parameters determined from this study from the sorption 2 edge data with $\mathrm{R}_{\mathrm{s} / \mathrm{w}}=0.005$ and those reported by Waite et al. (1994).

3

\begin{tabular}{ccc} 
& This study & Waite model \\
\cline { 2 - 3 } mole strong sites per mole $\mathrm{Fe}^{*}$ & 0.00102 & 0.0018 \\
& & \\
Surface Complex & \multicolumn{2}{c}{$\log ($ formation constant $)$} \\
\hline$\left(\equiv \mathrm{Fe}_{\mathrm{S}} \mathrm{O}_{2}\right) \mathrm{UO}_{2}$ & -2.17 & -2.57 \\
$\left(\equiv \mathrm{Fe}_{\mathrm{w}} \mathrm{O}_{2}\right) \mathrm{UO}_{2}$ & -7.06 & -6.28 \\
& & \\
$\left(\equiv \mathrm{Fe}_{\mathrm{S}} \mathrm{O}_{2}\right) \mathrm{UO}_{2} \mathrm{CO}_{3}{ }^{2-}$ & 2.67 & 3.67 \\
$\left(=\mathrm{Fe}_{\mathrm{w}} \mathrm{O}_{2}\right) \mathrm{UO}_{2} \mathrm{CO}_{3}{ }^{2-}$ & -1.43 & -0.42
\end{tabular}

*both models assume 0.875 mole total sites per mole Fe

4

5

6 
$5 \quad{ }^{a}$ RMSE $=$ root mean squared error $=\sqrt{\sum_{i=1}^{n}\left(y_{i, p r e d}-y_{i, o b s}\right)^{2} /(n-p)} ; y_{i, p r e d}$ and $y_{i, o b s}=$ model predicted and observed data points,

6 respectively; $n=$ number of observations; $p=$ number of adjustable parameters in the model. * 4-parameter model provided

7 significantly better fit than the 2-parameter model $(P<0.01)$.

Forward rate constants $\left(\mathrm{k}_{\mathrm{f}}, \mathrm{k}_{\mathrm{f} 2}\right)$ fitted and the backward rate constants $\left(\mathrm{k}_{\mathrm{b}}, \mathrm{k}_{\mathrm{b} 2}\right)$ estimated based on the stipulation that the ratio $\mathrm{k}_{\mathrm{f}} / \mathrm{k}_{\mathrm{b}}$ is fixed and equal to the fitted equilibrium model formation constants (Table 2).

\begin{tabular}{|c|c|c|c|c|c|c|c|c|}
\hline $\mathrm{R}_{\mathrm{s} / \mathrm{w}}$ & $\begin{array}{c}\mathrm{C}_{0} \\
(\mu \mathrm{M})\end{array}$ & $\begin{array}{c}k_{\mathrm{f}} \\
\left(\mathrm{h}^{-1} \mathrm{M}^{-1}\right)\end{array}$ & $\begin{array}{c}k_{b} \\
\left(h^{-1} M^{-2}\right)\end{array}$ & $\begin{array}{c}\mathrm{k}_{\mathrm{f} 2} \\
\left(\mathrm{~h}^{-1} \mathrm{M}^{-1}\right)\end{array}$ & $\begin{array}{c}\mathrm{k}_{\mathrm{b} 2} \\
\left(\mathrm{~h}^{-1} \mathrm{M}^{-2}\right)\end{array}$ & $\mathrm{RMSE}^{\mathrm{a}}$ & $\log \left(k_{\mathrm{f}} / \mathrm{k}_{\mathrm{b}}\right)$ & $\log \left(\mathrm{k}_{\mathrm{f} 2} / \mathrm{k}_{\mathrm{b} 2}\right)$ \\
\hline 0.005 & 1 & $1.11 \mathrm{E}+04$ & $1.65 \mathrm{E}+06$ & $2.56 \mathrm{E}+06$ & $2.87 \mathrm{E}+13$ & 0.2929 & -2.17 & -7.06 \\
\hline 0.25 & 1 & $1.13 \mathrm{E}+03$ & $1.68 \mathrm{E}+05$ & $2.47 \mathrm{E}+05$ & $2.77 \mathrm{E}+12$ & 0.1182 & “" & “" \\
\hline 2 & 1 & $5.26 \mathrm{E}+05$ & $7.78 \mathrm{E}+07$ & $3.56 \mathrm{E}+01$ & $4.00 \mathrm{E}+08$ & 0.0008 & ، & ، \\
\hline 0.005 & 10 & $6.29 \mathrm{E}+03$ & $9.30 \mathrm{E}+05$ & $1.93 \mathrm{E}+04$ & $2.17 \mathrm{E}+11$ & 1.5707 & “6 & “6 \\
\hline 0.25 & 10 & $1.30 \mathrm{E}+05$ & $1.92 \mathrm{E}+07$ & $6.94 \mathrm{E}+02$ & 7.79E+09 & 0.3281 & “6 & “6 \\
\hline 2 & 10 & $5.93 \mathrm{E}+05$ & 8.77E+07 & $1.00 \mathrm{E}-38$ & $1.12 \mathrm{E}-31$ & 0.0202 & 66 & 6 \\
\hline
\end{tabular}

Forward and reverse rate constants adjusted to fit the model to the data (ratio $\mathrm{k}_{\mathrm{f}} / \mathrm{k}_{\mathrm{b}}$ allowed to vary).

\begin{tabular}{|c|c|c|c|c|c|c|c|c|}
\hline $\mathrm{R}_{\mathrm{s} / \mathrm{w}}$ & $\begin{array}{c}\mathrm{C}_{0} \\
(\mu \mathrm{M})\end{array}$ & $\begin{array}{c}\mathrm{k}_{\mathrm{f}} \\
\left(\mathrm{h}^{-1} \mathrm{M}^{-1}\right)\end{array}$ & $\begin{array}{c}\mathrm{k}_{\mathrm{b}} \\
\left(\mathrm{h}^{-1} \mathrm{M}^{-2}\right)\end{array}$ & $\begin{array}{c}\mathrm{k}_{\mathrm{f} 2} \\
\left(\mathrm{~h}^{-1} \mathrm{M}^{-1}\right)\end{array}$ & $\begin{array}{c}\mathrm{k}_{\mathrm{b} 2} \\
\left(\mathrm{~h}^{-1} \mathrm{M}^{-2}\right)\end{array}$ & $\mathrm{RMSE}^{\mathrm{a}}$ & $\log \left(\mathrm{k}_{\mathrm{f}} / \mathrm{k}_{\mathrm{b}}\right)$ & $\log \left(\mathrm{k}_{\mathrm{f} 2} / \mathrm{k}_{\mathrm{b} 2}\right)$ \\
\hline 0.005 & 1 & $1.02 \mathrm{E}+06$ & $5.94 \mathrm{E}+07$ & 5.62E-01 & $1.50 \mathrm{E}+10$ & $0.0504 *$ & -1.77 & -10.43 \\
\hline 0.25 & 1 & $6.15 \mathrm{E}+05$ & $3.66 \mathrm{E}+07$ & $7.31 \mathrm{E}+03$ & $8.10 \mathrm{E}+13$ & $0.0157 *$ & -1.77 & -10.04 \\
\hline 2 & 1 & $2.11 \mathrm{E}+05$ & $1.69 \mathrm{E}+07$ & $4.13 \mathrm{E}+02$ & $1.53 \mathrm{E}+08$ & $0.0004 *$ & -1.90 & -5.57 \\
\hline 0.005 & 10 & $1.06 \mathrm{E}+05$ & $1.00 \mathrm{E}-38$ & $9.69 E+03$ & $9.85 \mathrm{E}+09$ & $0.7523 *$ & 43.03 & -6.01 \\
\hline 0.25 & 10 & $2.79 \mathrm{E}+05$ & $4.37 \mathrm{E}+07$ & $1.00 \mathrm{E}-38$ & $7.61 \mathrm{E}+09$ & $0.2530 *$ & -2.19 & -47.88 \\
\hline 2 & 10 & $6.25 \mathrm{E}+05$ & $1.27 \mathrm{E}+08$ & $1.00 \mathrm{E}-38$ & $1.00 \mathrm{E}-31$ & 0.0201 & -2.31 & -7.00 \\
\hline
\end{tabular}


2 Figure 1. Observed, fitted and predicted U(VI) sorption as a function of $\mathrm{pH}$. Two solid:solution 3 ratios, $\mathrm{R}_{\mathrm{s} / \mathrm{w}}$, of 0.005 and 0.25 were used. Error bars representing \pm 1 standard error are smaller

4 that the symbols. The solid line represents the surface complexation model fit to the $\mathrm{R}_{\mathrm{s} / \mathrm{w}} 0.005$

5 data; the dashed line shows the prediction for $\mathrm{R}_{\mathrm{s} / \mathrm{w}} 0.005$ from Waite's model (1994); the dash-

6 dot line shows the predicted $\mathrm{U}(\mathrm{VI})$ sorption edge for $\mathrm{R}_{\mathrm{s} / \mathrm{w}} 0.25$ using the optimized parameter set.

7 The initial U(VI) concentration is $4.2 \mu \mathrm{M}$. The upper panel indicates the estimated distribution of 8 sorbed $\mathrm{U}$ on surface sites for the $\mathrm{R}_{\mathrm{S} / \mathrm{w}} 0.005$ case (see equations 1a through $2 b$ ).

10 Figure 2. Observed and predicted $\mathrm{U}(\mathrm{VI})$ sorption isotherms. (a) data for all $\mathrm{R}_{\mathrm{s} / \mathrm{w}}$ conditions

11 tested. Panels (b), (c), and (d) data and model predicted U(VI) sorption isotherms. The 12 experimental $\mathrm{pH}$ is indicated in each panel. Error bars representing \pm 1 standard error are

13 smaller than the symbols. The horizontal line in each panel indicates the concentration of strong 14 sites (mole/kg) according to our optimized parameter set. The vertical dashed line in each panel 15 indicates $\mathrm{U}(\mathrm{VI})$ aqueous concentration in equilibrium with the solid phase schoepite $\left(\mathrm{UO}_{3} \cdot 2 \mathrm{H}_{2} \mathrm{O}\right)$.

16 Uranyl-carbonate surface complexes are predicted to make a minor contribution to U sorption 17 (panel (c)).

19 Figure 3. Experimental and modeling results of sorption kinetic experiments with the initial $20 \mathrm{U}(\mathrm{VI})$ concentration of (a) $1 \mu \mathrm{M}$ and (b) $10 \mu \mathrm{M}$; error bars represent \pm 1 standard error. The 21 dashed lines represent the model fit when stipulating that the $\mathrm{k}_{\mathrm{f}} / \mathrm{k}_{\mathrm{b}}$ ratio is equal to the fitted 22 equilibrium model formation constant. The solid lines represent the model fit when the ratio $23 \mathrm{k}_{\mathrm{f}} / \mathrm{k}_{\mathrm{b}}$ is allowed to vary. The vertical line in panel (b) indicates the fluid residence time for the 
1 transport experiment. Uranium concentration in equilibrium with schoepite at the experimental

$2 \mathrm{pH}$ is $\sim 220 \mu \mathrm{M}$.

3

4 Figure 4. Observed and predicted breakthrough curves for the packed saprolite column. The

5 upper panel shows the bromide breakthrough curve and model fit obtained by adjusting the value

6 of the dispersion coefficient. Vertical dashed lines in the lower panel indicate when the washout

7 phase of the experiment began and when the flow interrupt manipulation was performed. Inset:

8 detailed presentation of the data in the few pore volumes surrounding the slow interrupt. 

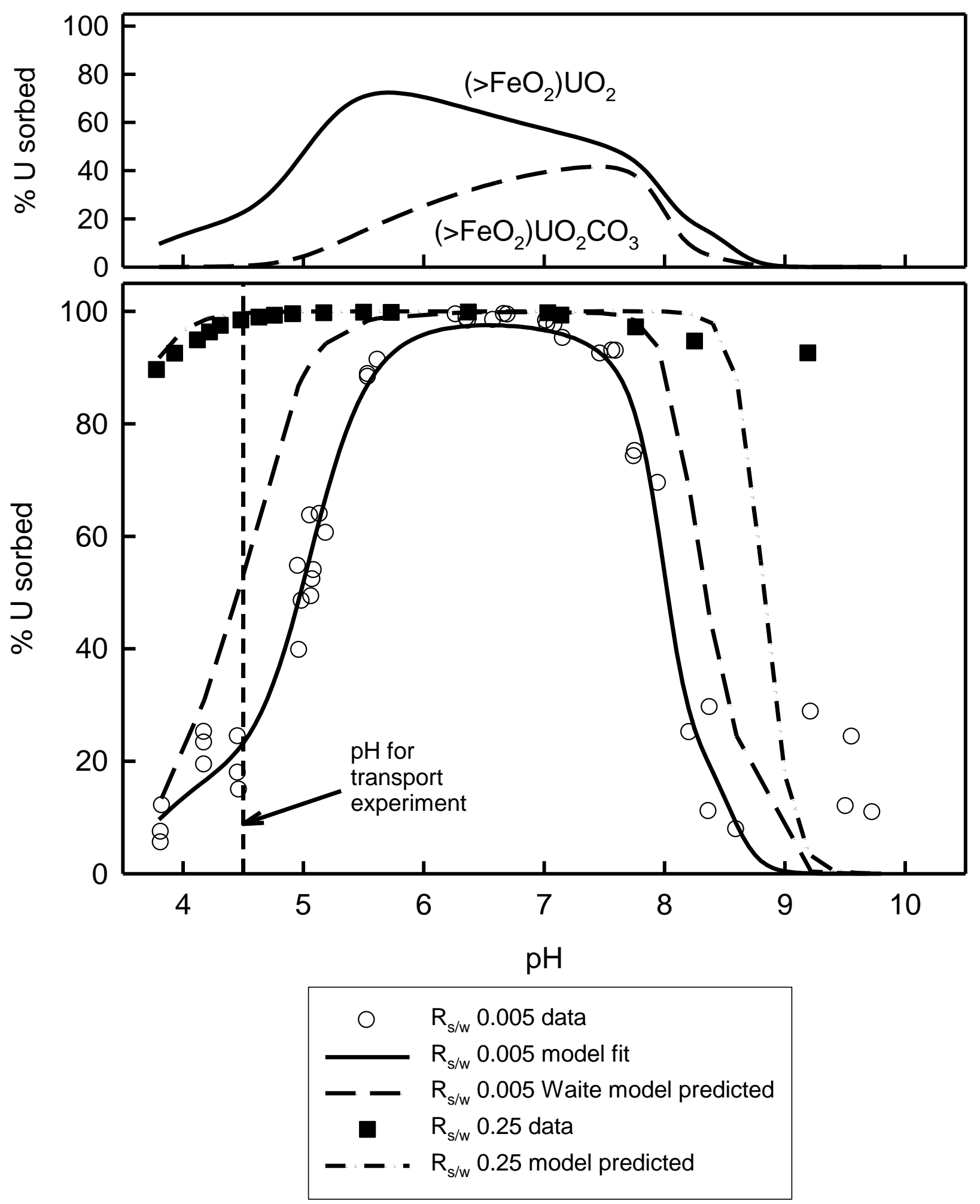

1 Figure 1. 


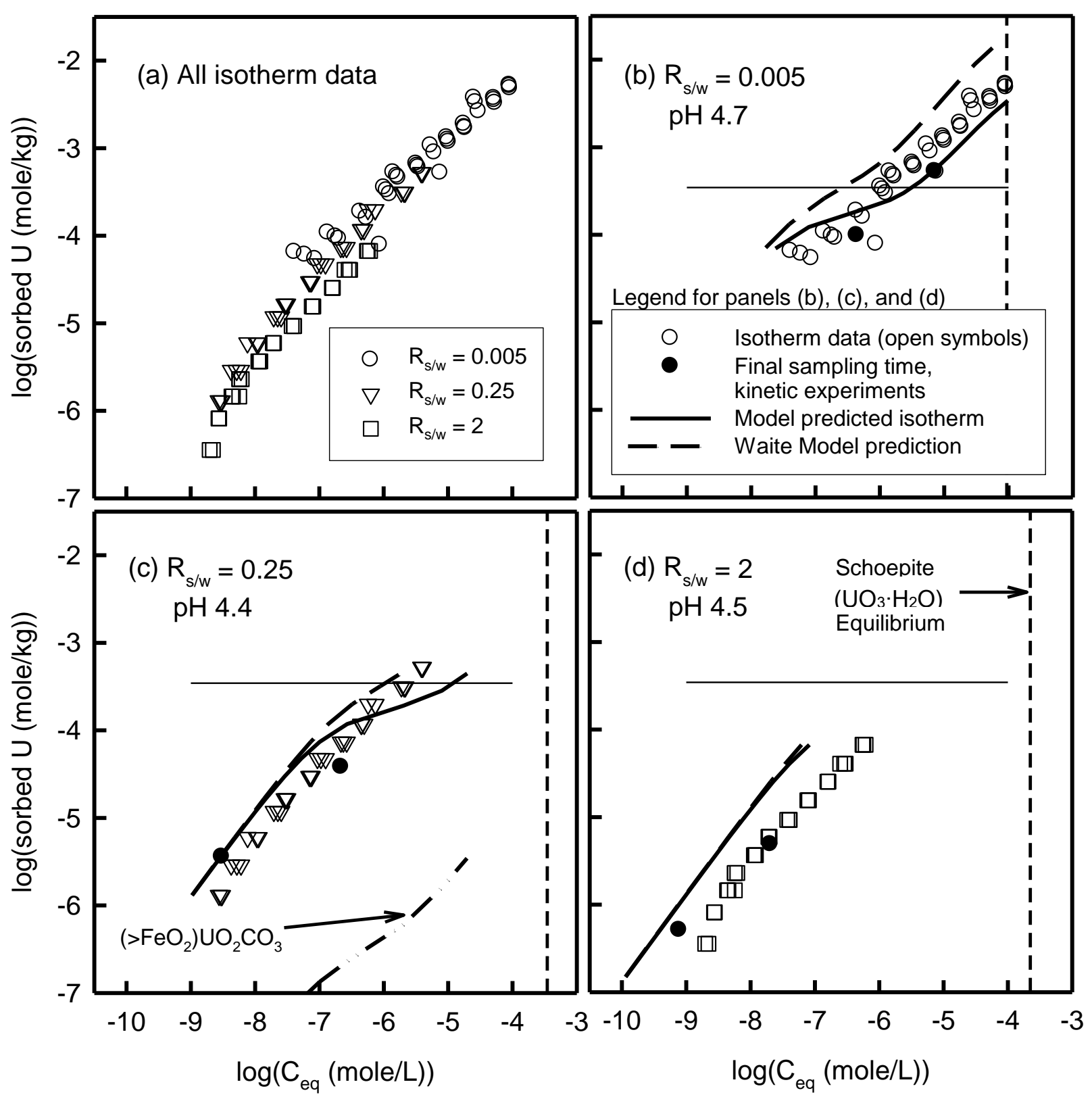

Figure 2. 

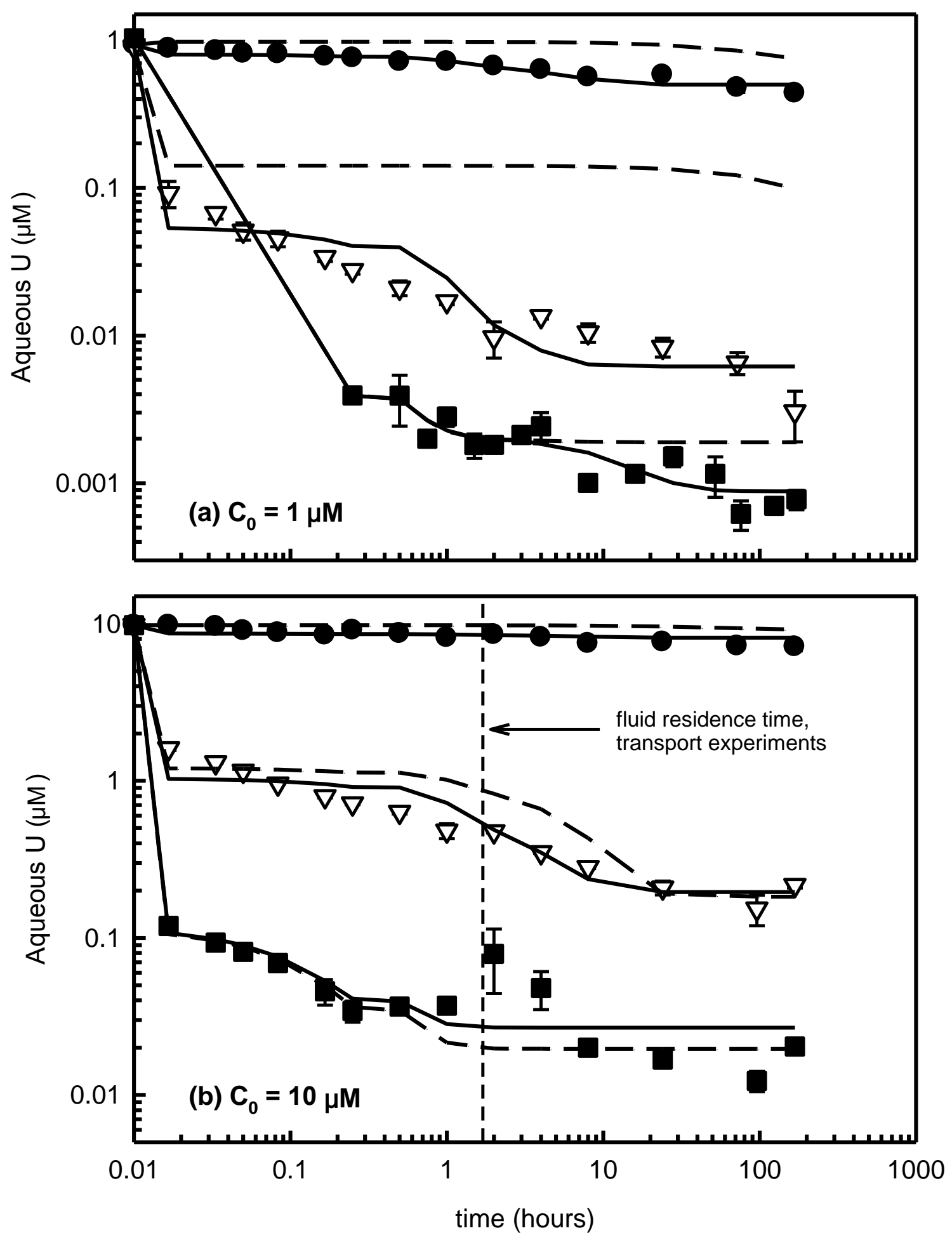

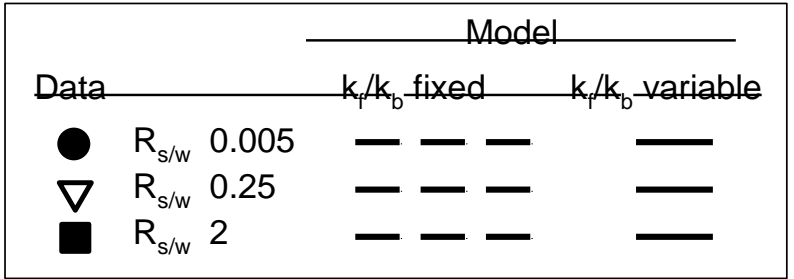

$1 \quad$ Figure 3. 

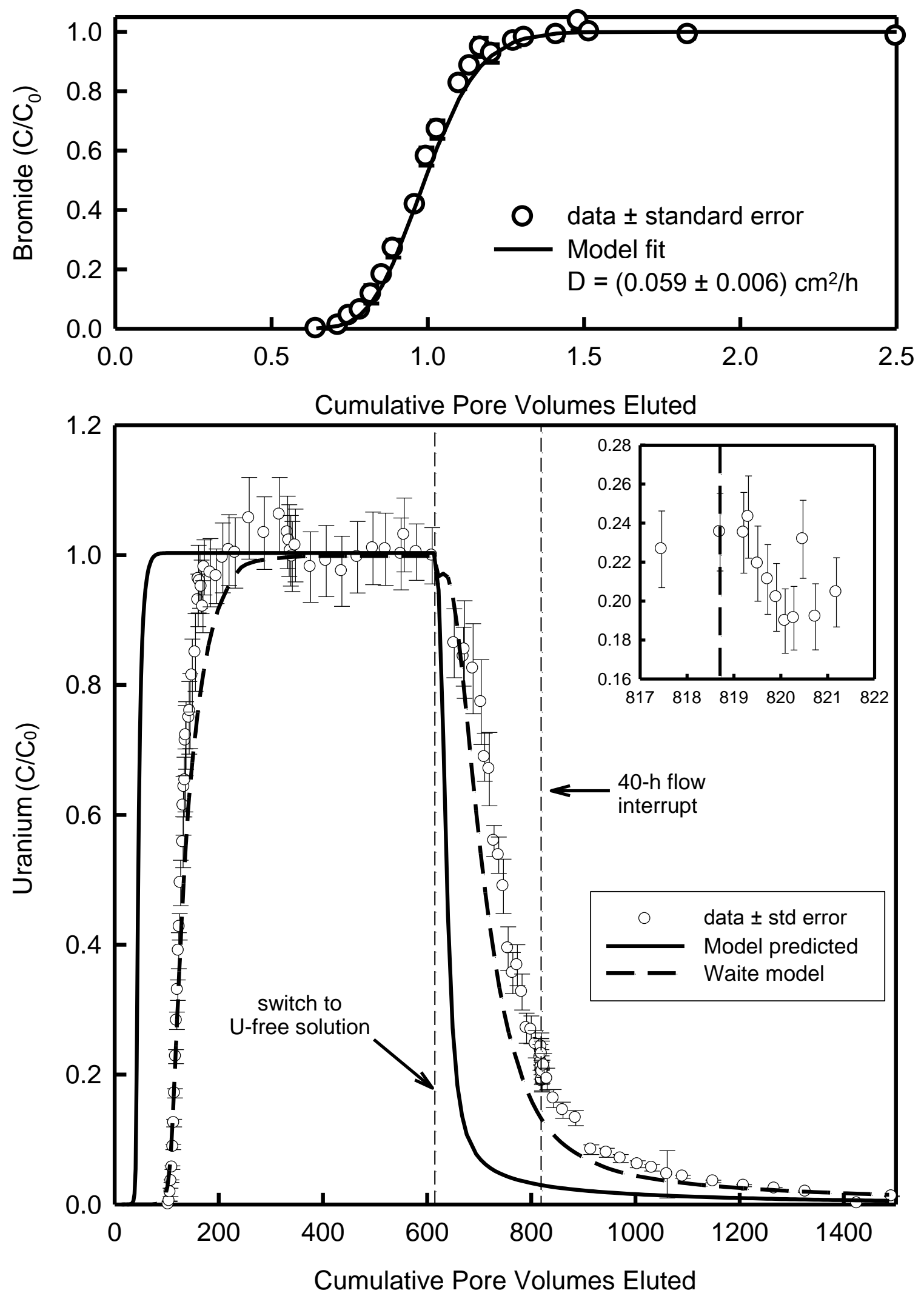

$1 \quad$ Figure 4. 